\title{
MR. H. N. RIDLEY'S HUNDREDTH BIRTHDAY
}

\author{
By J. W. PURSEGLOVE \\ Director of the Botanic Gardens, Singapore
}

$\mathrm{D}^{\mathrm{E}}$ ECEMBER 10, 1955, marks the hundredth birthday anniversary of $\mathrm{Mr}$. Henry Nicholas Ridley, C.M.G., F.R.S. He was director of the Singapore Botanic Gardens during 1888-1912, and he will always be remembered in South-East Asia for his vital role in the foundation of the rubber industry and for his gargantuan contribution to our knowledge of the natural history of the area.

While still at school at Haileybury, he decided to devote his life to the study of natural history in the tropics. After graduation at Exeter College, Oxford, he was awarded the Burdett-Coutts Geological Scholarship. In 1880 he was appointed to the staff of the Botany Department of the British Museum in charge of monocotyledons, where he worked until 1887. During this period he became acquainted with many tropical plants and published papers on them. In 1887 he explored the island of Fernando de Noronha, Brazil, and later published accounts of its flora, fauna and geology.

Thus when Ridley arrived in Singapore in November 1888 as the first scientific director of gardens and forests, Straits Settlements, he was well qualified for the tasks which lay ahead. The Singapore Botanic Gardens had been founded on their present site in 1859, although there had been. an earlier garden started by Raffles in 1822. Ridley's capability as a research worker and his work on economic crops and tropical botany succeeded in a surprisingly short time in pushing the Singapore Gardens to the fore as a centre of this work.

In the Economic Gardens, now the site of the University of Malaya, he found a plantation of Hevea rubber trees, produced from seedlings sent out by Sir Joseph Hooker from Kew in 1877, where they had been grown from seeds collected in Brazil by Mr. H. A. (later Sir Henry) Wickham. Tho seeds had not been smuggled out of Brazil as is often suggested, but had been obtained by the goodwill and co-operation of the Brazilian Government. Ridley at once began his famous tapping experiments, in which he demonstrated that the trees could be tapped regularly. Recently he told me that when he began he had no idea that rubber would be "a permanently milking tree". This work, together with his experiments on the preparation of rubber and his constant advocacy of it as a plantation crop, often in the face of opposition, led to the foundation of the present industry upon which so large a share of the wealth of Malaya and the eastern tropies has rested. Ridley remained in Malaya long enough to see the fruition of his labour and the great rubber boom of 1910 . O. D. Gallagher, in an article in The Observer of June 25, 1955, writes: "He is one of the hundred or so men, out of the 2,500 million alive to-day, whose personal efforts have helped decisively to shape our modern life. His rewards have been meagre and mainly abstract. ... Ridley's name is indelibly rubber-stamped in history."

Ridley's work on economic crops was not confined to rubber; he carried out experiments with most of the actual and potential tropical crops known. He provided not only local planters, but also all other tropical parts of the Empire and elsewhere, with planting material of rubber and many other erops. Visitors from all over the world came to see his experimental and demonstration plots. As early as I 889 he reported that cocoa would probably be profitable on the better Malayan soils, while in 1907 he directed attention to the possibility of oil palm as a plantation crop. Ridley produced the first written works of their kind on Malayan timbers, rattans and other forest products, as well as drug plants, fruits and spices. It should be realized that until the formation of the Agricultural Department in Malaya in 1904, Ridley and his three assistants at Singapore, Malacea and Penang were the only trained men to whom the planting community could apply for technical advice and help. Ridley studied in some detail the pests and diseases of the economic crops of the area, and specimens were often submitted to him by the planters for identification with requests for advice on their control. In 1891 he founded the Agricultural Bulletin, so that he could supply the planting community and others with information resulting from his many investigations. $\mathrm{He}$ continued to edit it until his retirement in 1912, and from 1900 it was published monthly.

"Mr. Ridley's work as a field botanist added more than that of any other single man to our knowledge of the flora of the Malay Pensinsula; his Flora $(1922-25)$ is the foundation upon which all future work must rest." He was an indefatigable collector and a tireless worker. He made excursions to most parts of Malaya, often remote, as well as visiting Cocos and Christmas Islands, Borneo, Java and Sumatra. In all, he collected many thousands of specimens, of which a large number were then unknown to science. He named for the first time a few thousand plants, and a surprising number of Malayan plants are still only known from his original gatherings. Nor did he confine himself to plants, of which he collected all groups, but he also collected many animals as well, mainly vertebrates (excluding fish) and insects. Many plants and animals were named in his honour, including a New Guinea genus of orchids Ridleyella and a moth genus Ridleyana. It was Ridley who discovered that the ant Oecophylla smarangdina uses its own larvæ to make silk for the construction and repairing of its nest. Ridley added very considerably to the collection of cultivated plants, both Malayan and exotic, in the Botanic Gardens, Singapore, and brought back living plants from many of his excursions for growing here. He sent seeds of the more spectacular plants to Kew, where they were flowered for the first time in Europe. Hand-coloured illustrations and descriptions of some of these were published in Curtis's Botanical Magazine, of which Vol. 132 (1906) was dedicated to Mr. Ridley.

His first scientific paper was published while he was still at school, and in all he published more than five hundred papers, articles and books; amounting to some ten thousand printed pages, dealing with tropical agriculture, botany, zoology and geology. A full list of his publications up to 1935 is given in the Gardens' Bulletin (9), which was dedicated to him 
on his eightieth birthday. His encyclopedic volume, "The Dispersal of Plants throughout the World", embodying many original observations, was published in 1930 when he was seventy-five. Commenting on his published work, one critic has said: "That there were inaccuracies goes without saying, but it was just that quality of recklessness in Ridley's work that enabled him to turn out such vast quan. tities of assimilable knowledge when it was most needed. A lesser man would have feared for his professional reputation, but Ridley was above such petty considerations. The work needed doing, and with the means at his disposal he did it magnificently".

Mr. Ridley was secretary of the Royal Asiatic Society, Straits Branch, during 1889-1911, and editor of its journal, in which he published many original papers. In 1905 he gave the first course of botany lectures to the newly formed King Edward VII College of Medicine, now the Medical School at the
University of Malaya, and continued these lectures until 1910.

Mr. Ridley was elected a Fellow of the Linnean Society in 1881 and of the Royal Society in 1907. His services were recognized by the honour of a C.M.G. in 1911. His work as a naturalist and in establishing the Para rubber industry has been recognized officially by various scientific and industrial bodies. We are planning appropriate celebrations at the Botanic Gardens, Singapore, on his hundredth birthday, which will include an exhibition of "Ridleyana".

It is my fervent hope that the Singapore Botanic Gardens may long continue as a leading centre of research in tropical botany and a worthy memorial to Mr. Ridley and all that he has done for us during his long and productive life. I am sure that readers of Nature will join with $\mathrm{me}$ in congratulating $\mathrm{Mr}$. Ridley on the present happy occasion of his centenary and in wishing him "Many Happy Returns".

\section{THE ROYAL SOCIETY}

\section{ANNIVERSARY ADDRESS* BY LORD ADRIAN, O.M., P.R.S.}

\section{AWARD OF MEDALS, 1955}

\section{Copley Medal : Sir Ronald Fisher, F.R.S.}

$\mathrm{T}$

$\mathrm{HE}$ rise of quantitative biology, which has been so noteworthy a feature of this century and especially of the past thirty years or so, has been due above all to the work of R. A. Fisher. The variability of living things posed problems and raised difficulties in the interpretation of experimental and observational data which made necessary something beyond the methods of the physical sciences. They required in fact a new approach to inductive inference, and one which would provide means of drawing conclusions of assessable reliability from variable material often available only in small samples. It is to Fisher's combination of mathematical skill and biological insight that we owe the developments, both theoretical and practical, which have done so much towards solving this problem and so making biologists of virtually every kind quantitative in their experiment, their analysis, and, most important of all, their thought.

Faced with the agronomical problems of Rothamsted, the staff of which he joined in 1919, Fisher began the remarkable series of statistical investigations which gave us the techniques described in "Statistical Methods", the tabular matter of "Statistical Tables" (published with F. Yates) for facilitating their use, and the philosophy of "Design of Experiments" by which they may be understond, appreciated and extended. The outcome has not merely stood the test of time in those branches of biology with which Fisher was immediately concerned, but also has had an ever-widening influence which now extends even beyond the borders of biology itself. In building the new biometry, Fisher has given especially to the younger biologists a confidence and quantitative

* Delivered at the Royal Society on November 30. outlook the full effect of which we have still to see.

While Fisher will always be associated chiefly with these developments in statistics and biometry, it should not be forgotten that he has made outstanding contributions in the field of geneties and evolu. tion. He set us on the way towards the modern study of biometrical genetics, and his mathematical treatment of natural selection has provided the basis for much of our present studies of populations. His theory of the evolution of dominance introduced us to the notion of the modification by selection of gene expression, and we owe primarily to him the theory by which we came to understand the working of the Rhesus blood groups. He has indeed long been established internationally as well as nationally as one of our leading geneticists, than whom few have done more to further the understanding of evolutionary processes.

\section{Royal Medal (A): Sir Alexander Todd, F.R.S.}

Over a wide field, Todd has made distinguished original contributions to the chemistry of natural products, more particularly in the field of compounds of physiological importance. His remarkable contributions to knowledge and his brilliance as an investigator have been recognized internationally by both organic chemists and biologists.

Todd joined Sir Robert Robinson in 1931 and played an important part in investigations on the synthesis of anthocyanins. His earlier work included major contributions in the field of vitamin chemistry, for example, in relation to the development of the structure of vitamin $B_{1}$, and to its synthesis. Independent of Karrer and Fernholz, Todd established the structure of vitamin $\mathrm{E}$ and achieved a synthesis. More recently, he has turned his attention to the vitamin $B_{12}$ group, and his degradative and synthetical 